\title{
HAL1 mediate salt adaptation in Arabidopsis thaliana
}

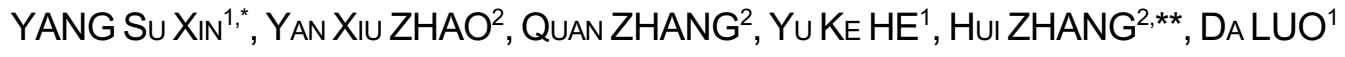 \\ 1 Institute of Plant Physiology, Shanghai Institutes for Biological Sciences, Chinese Academyof Science, 300 \\ Fenglin Road, Shanghai 200032, China \\ 2 Key Laboratory of Plant Stress Research, Shandong Normal University, Jinan 250014, China
}

\begin{abstract}
The yeast HAL1 gene was introduced into Arabidopsis thaliana by Agrobacterium tumefaciens-mediated transformation with vacuum infiltration under the control of CaMV 35S promoter. Thirty-three individual kanamycin resistant plants were obtained from 75,000 seeds. Southern blotting analysis indicated that $H A L 1$ gene had been integrated into all of the transgenic plants'genomes. The copy number of HAL1 gene in transgenic plants was mostly 1 to 3 by Southern analysis. Phenotypes of transgenic plants have no differences with wild type plants. Several samples of transformants were self-pollinated, and progenies from transformed and non-transformed plants (controls) were evaluated for salt tolerance and gene expression. Measurement of concentrations of intracellular $\mathrm{K}^{+}$and $\mathrm{Na}^{+}$showed that transgenic lines were able to retain less $\mathrm{Na}^{+}$than that of the control under salt stress. Results from different tests indicated the expression of HAL1 gene promotes a higher level of salt tolerance in vivo in the transgenic Arabidopsis plants.
\end{abstract}

Key words: Salt-tolerant, Arabidopsis, HAL1, gene engineering.

\section{INTRODUCTION}

Salinity is a major environmental stress that is a substantial constraint to crop production both for dry land and irrigated agriculture. The detrimental impact of this stress is perpetuated and exacerbated by management practices used to facilitate high-output crop production. To overcome these limitations and improve production efficiency in the face of a burgeoning world population, more salt tolerant crops must be developed. In contrast with traditional breeding, the direct introduction of a small number of genes by genetic engineering seems to be a more attractive and rapid approach to improving salt tolerance.

The maladies caused by salt stress arise from the disruption of cellular aqueous and ionic equilibrium, so tolerance determinants include factors that function to restore cellular homeostasis. A manifest engineering stage for salt adaptation of

\footnotetext{
* The present address of the author is Shanxi Normal University, Xian 710062, China

** Author for correspondence. Fax: 0086-531-296654; E-mail: zhangh@sdnu.edu.cn

Received Sept-18-2000 Revised April-19-2001 Accepted April-23-2001
}

high plants is protecting the equilibrium of cellular aqueous status. Recently, results from metabolic engineering experiments have confirmed the functional roles for compatible osmolytes, such as mannital, proline, and betaine, in salt adaptation of high plants[1], [2],[3]. These compounds are presumed to function both in osmoprotection and osmotic adjustment. But, unfortunately, they seemed to contribute minutely to salt tolerance of plant individually in engineering experiments[4].

Another interesting stage might be the introduction of genes that modulate cation transport system to balance ion homeostasis. The candidates of these genes involve in those restricting $\mathrm{Na}^{+}$uptake across the plasma membrane, facilitating $\mathrm{Na}^{+}$and $\mathrm{Cl}$ - sequestration into the vacuole, and modulating signaling pathways that control ion homeostasis. Apse et al[5] reported the moderate over-expression of a homologous cDNA encoding a sodium/proton anti-porter could improve salinity tolerance on Arabidopsis. Alternatively, the expression of components of stress signaling pathways (e.g. constitutively active yeast calcineurin) has been used to 
achieve biochemical 'pathway' engineering involving multiple targets for salinity stress tolerance by improving ion homeostasis[6].

In yeast, the genes that modulate cation transport systems have been identified[7]. HAL1 and HAL3, which involved in the regulation of $\mathrm{K}^{+}$and $\mathrm{Na}^{+}$transport, respectively, considerably enhance salt tolerance in yeast. HAL1 over-expression improves growth in media with high $\mathrm{NaCl}$ concentrations by decreasing $\mathrm{Na}^{+}$and retaining $\mathrm{K}^{+}$[8], [9]. In addition, transgenic melon[10] and tomato[4] plants expressing the HAL1 gene showed a certain level of salt tolerance. Here we reported the introduction of the yeast HAL1 gene into Arabidopsis and studied germination and physiological responses in both transgenic and wild type plants under stressed and non-stressed conditions. In addition, we have traced back the increased salt tolerance of transgenic lines to alterations in $\mathrm{Na}^{+}$ and $\mathrm{K}^{+}$homeostasis.

\section{MATERIALS AND METHODS}

\section{Materials}

The following chemicals and reagents were purchased from Promega Corporation or Sigma-Aldrich Corporation.

\section{Growth parameters and germination studies}

Arabidopsis thaliana (ecotype Landsberg erecta) plants were grown in the greenhouse under a $16 \mathrm{~h}$ light and $8 \mathrm{~h}$ dark cycle at $25^{\circ} \mathrm{C}$. For germination study, wild type and transgenic surfacesterilized Arabidopsis seeds were sown in Petri dishes containing $25 \mathrm{ml}$ MSS medium [MS (Murashige and Skoog, 1962[11]) + $1 \%$ sucrose], $\mathrm{MSS}+100 \mathrm{mM} \mathrm{NaCl}$, and $\mathrm{MSS}+200 \mathrm{mM} \mathrm{NaCl}$. Approximately 100 seeds were placed on each $8 \mathrm{~cm}$ petri dish. Germination was scored after $7 \mathrm{~d}$ of germination under condition as described above.

\section{Plasmid construction and plant transformation}

The HAL1 open reading frame was amplified using the Saccharomyces cerevisiae genomic DNA as template with primer 5'-CGGGATCCATGGATTTCAAAGATTTAGGATT- GCATG-3' (annealed to the start codon) and primer 5\% GGGGTACCTTTTTCAACTATTCTGT GTTGATTG-3' (annealed to the stop codon). PCR conditions were as follows: $940 \mathrm{C}$ for $1 \mathrm{~min}$, followed by 35 cycles of $94^{\circ} \mathrm{C}$ for 45 second, 55 oC for 45 second, $72{ }^{\circ} \mathrm{C}$ for $1 \mathrm{~min}$, and $72^{\circ} \mathrm{C} 10 \mathrm{~min}$. HAL1 PCR products were confirmed by sequence analysis on an Applied Biosystem 373 Automated DNA sequencer (ABI/Perkin-Elmer, Foster city, CA). The ORF region of HAL1 is $879 \mathrm{bp}$, as identified by Gaxiola et al[8]. This HAL1 PCR product was inserted into binary plant vector pROK2[12], between the cauliflower mosaic virus CaMV 35S promoter and octopone synthase (Ocs) terminator. The resulting plasmid, named pROK-HAL1, was mobilized to Agrobacterium tumefaciens strain LBA4404[13] using Escherichia coli HB101 by tri-pareintal crosses and used for plant transformation.

Arabidopsis thaliana adult plants ( $5 \mathrm{w}$ old) were infected by vacuum infiltration with Agrobacterium tumefaciens mediated transformation[14] and grown in the greenhouse to collect seeds. These seeds were screened in MSS medium supplemented with $50 \mathrm{mg} / \mathrm{ml}$ kanamycin.

\section{Southern and Northernanalysis}

Southern and Northern blotting experiments were performed using approximately $5 \mathrm{mg}$ genomic DNA and $50 \mathrm{mg}$ total RNA per track. DNA probes were labeled by $a-\left[{ }^{32} P\right]-d C T P$ according to the manufacture's instructions (Promega Corporation). Hybridization was performed in PSE ( $0.3 \mathrm{M}$ sodium phosphate $\mathrm{pH} 7.2,7 \% \mathrm{SDS}, 1 \mathrm{mM}$ EDTA) at $65^{\circ} \mathrm{C}$ for Southern and at $55^{\circ} \mathrm{C}$ for Northern[15]. Filters were washed at high stringency $\left(0.1 \times \mathrm{SSC}, 0.1 \%\right.$ SDS at $\left.65^{\circ} \mathrm{C}\right)$ for $30 \mathrm{~min}$. Hybridization was detected by exposure to $\mathrm{X}$-ray film and quantified withaPhosphor-Imager(MolecularDynamics,STORM840).

\section{Determination of $\mathrm{K}^{+}$and $\mathrm{Na}^{+}$content}

Transgenic T3 plants from several lines of single copy insertion of foreign HAL1 were used in assessing salt tolerance. Twenty transformed plants of each of these lines were grown under a short-day cycle ( $8 \mathrm{~h}$ light, $16 \mathrm{~h}$ dark). Each set of 20 plants was divided into four groups. We applied $25 \mathrm{ml}$ of a diluted nutrient solution ( $1 / 8 \mathrm{MS}$ salts) every other day over the $16 \mathrm{~d}$ watering treatment. The control group received no $\mathrm{NaCl}$ supplementation. The other three groups watered with nutrient solutions supplemented with additional $\mathrm{NaCl}$, every $4 \mathrm{~d}$ for four times. The first group watered with nutrient solution containing $50 \mathrm{mM} \mathrm{NaCl}$ in all four times; the second group watered with nutrient solutions containing $50 \mathrm{mM}, 100 \mathrm{mM}, 100 \mathrm{mM}$ and 100 $\mathrm{mM} \mathrm{NaCl}$ respectively. The last group watered with nutrient solutions containing $50 \mathrm{mM}, 100 \mathrm{mM}, 150 \mathrm{mM}$ and $200 \mathrm{mM}$ $\mathrm{NaCl}$ successively. The root, lower tissue, middle tissue, and top tissue of plants were harvested at the end of the salt treatment. Dry weight was measured after $24 \mathrm{~h}$ at $70^{\circ} \mathrm{C}$. The samples were digested with $\mathrm{HNO}_{3}$, and $\mathrm{K}^{+}$and $\mathrm{Na}^{+}$concentrations were determined by atomic absorption spectrophotometer (AA-680). Values are the mean $\pm S D(n=4)$.

\section{RESULTS}

\section{Genetic transformation and segregation pattern}

Five-week-old Arabidopsis thaliana (Lansberg erecta) plants were infected with Agrobacterium tumefaciens carrying the HAL1 and the nptll genes in the plasmid pROK-HAL 1 by vacuum transformation. Thirty-three individual kanamycin resistant plants were obtained from 75,000 seeds. The initial kanamycin resistant plants are named hereafter as T1; T1 plant should be hemizygous for the integrated foreign gene. The progeny obtained from a T1 transgenic plant (by self-cross) will be named as T2. T2 plants were checked for integration 
of foreign gene by counting ratio of the number of tolerant plants to the number of non-tolerant plants on selection medium with kanamycin. From each of the selected lines, 10 or more T2 tolerant plants were grown in green house. T2 plants self-cross obtained T3 plants. Homozygous lines (T3) that are all tolerant to kanamycin were selected, named H9903, H9905, H9928, H9929 et al, and used for phenotype characterization and further experiments.

Growth and phenotype of transgenic plants were found to have no differences with that of wild type plants. Inheritance of the transgenes was studied by testing the growth of seeds on media with kanamycin $(50 \mathrm{mg} / \mathrm{ml})$. Under selecting condition, progenies of fourteen lines of T2 plants developed in the proportion of three tolerant to one sensitive; while that of six lines of T2 plants developed in proportion of fifteen tolerant to one sensitive. According to the classical genetic theory, when transformed lines segregated in 3:1 in kanamycin, it suggest that a single copy of the construct insert into the plant genome; when transformed lines segregated in 15:1 with kanamycin, two copies into Arabidopsis genome (Tab 1). Above deduction could be authenticated by Southern hybridization in most of transformed lines, however, there are some antinomy between them such as transgenic line H9908 and H9917 (Tab 1).

\section{Molecularcharacterization of the regenerated plants}

After vacuum infiltration transformation of Arabidopsis thaliana and selection in $50 \mathrm{mg} / \mathrm{ml}$ kanamycin for three generations, we obtained the non-segregation lines to carry out the further molecular and physiological examinations.

T3 kanamycin tolerant plants were checked by PCR. The amplification was carried out in the presence of 5' primer according to the sequence of CaMV $35 \mathrm{~S}$ promoter and 3 ' primer of HAL1. An intense $900 \mathrm{bp}$ band corresponding in size to the HAL1 products was obtained from the kanamycin tolerant plants, while nothing was got from wild type plants. In order to confirm the amplification products, Southern hybridization was performed using HAL1 gene. It has been shown that all kanamycin tolerant plants have strong positive signals, and no signal was shown in wild type plant (Fig 1).

To characterize the copy number of integrated foreign HAL1 gene in transgenic plants, genomic DNA of T3 plant digested by EcoRI was hybridized with HAL1
Tab 1. The Knr:Kns ratio of some populations of transgenic plants

\begin{tabular}{cccccc}
\hline $\begin{array}{c}\text { Transgenic } \\
\text { line }\end{array}$ & $\begin{array}{c}\text { Green } \\
\text { seedling }\end{array}$ & $\begin{array}{c}\text { Yellow } \\
\text { seedling }^{*}\end{array}$ & $\begin{array}{c}\text { Green/yellow } \\
\text { seedling* }\end{array}$ & $\begin{array}{c}\text { Insert } \\
\text { number1 }\end{array}$ & $\begin{array}{c}\text { Insert } \\
\text { number2 }\end{array}$ \\
\hline H9903 & 111 & 46 & $2.4 / 1$ & 1 & 1 \\
H9905 & 89 & 30 & $3.3 / 1$ & 1 & 1 \\
H9908 & 190 & 64 & $3.0 / 1$ & 1 & 2 \\
H9911 & 600 & 34 & $17.4 / 1$ & 2 & 2 \\
H9916 & 128 & 19 & $6.7 / 1$ & 2 & 2 \\
H9917 & 138 & 46 & $3.0 / 1$ & 1 & 3 \\
H9920 & 118 & 39 & $3.0 / 1$ & 1 & 1 \\
H9923 & 95 & 9 & $10.5 / 1$ & 2 & 2 \\
H9926 & 97 & 8 & $12.0 / 1$ & 2 & 2 \\
H9928 & 228 & 79 & $2.9 / 1$ & 1 & 1 \\
H9929 & 73 & 18 & $4.0 / 1$ & 1 & 1 \\
\hline
\end{tabular}

${ }^{*}$ Growth on media with kanamycin $(50 \mathrm{mg} / \mathrm{ml})$,the tolerant seedlinge $\left(\mathrm{Kn}^{r}\right)$ are green while the sensitive $\left(\mathrm{Kn}^{\mathrm{s}}\right)$ are yel-low; the ratio of green/yellow seedling represents the inheritable character of transgenes.

Insert number ${ }^{1}$ is the copy number of GAL1gene deduced by genetic segregation of tolerant to kananycin in T2transgenic plants; Insert number ${ }^{2}$ is the copy number deduced from the results of Southern boltting in T3transgenic plants.

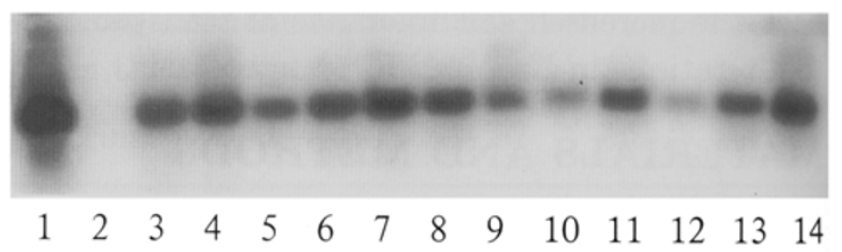

Fig 1. Southern blotting of PCR products of sone transgenic plants lane 1:pROK2+HAL1 plasmid,Lane2: wild type plants,Lanes 3-14: different transgenic plants (H9916;H9917;H9918;H9920;H9921;H9922;H9923; H9924;H9926;H9927;H9928;H9929.)

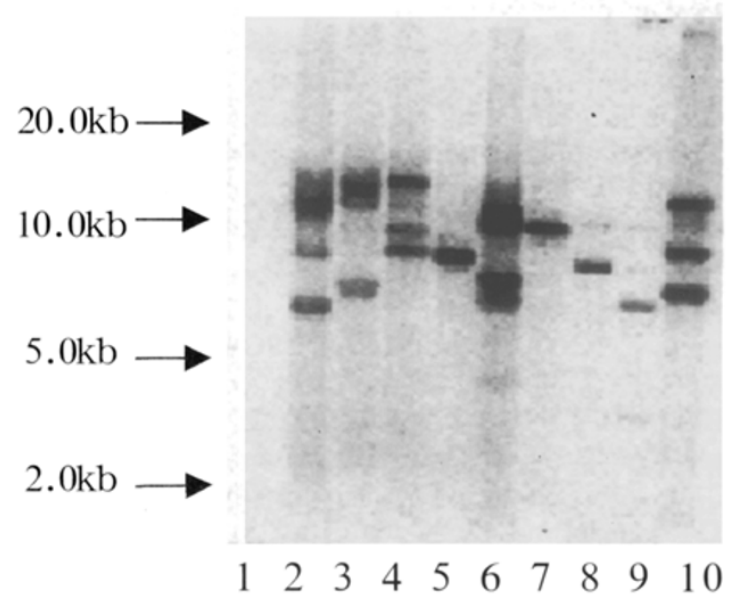

Fig 2. Southern blotting of wild type and some transgenic plants Lane 1:Wild type plants,Lanes2-10:different transgenic plants(H9901;H9916;H9918; H9929; H9926;H9928;H9903;H9905;H9912) 
probe. Southern blotting results showed that all transgenic plants have hybridization signals while wild type has nothing (Fig 2). The same results also showed that five lines have integrated a single copy of the HAL1 gene; five lines showed two fragments corresponding to two copies; and one line presented three integrated HAL1 copies (Tab 1). Copy numbers of HAL1 in transgenic plants are ranged from 1 to 3 .

Northern analysis revealed the presence of expression of HAL 1 mRNA in T3 plants of several non-segregation transgenic lines (Fig 3 ).

The effect of constitutive altered expression of HAL 1 on Arabidopsis growth and stress tolerance

To test for the ability to germinate under stress conditions, wild type and several non-segregation T3 transgenic plants'seeds were surface-sterilized and placed on agar containing levels of $\mathrm{NaCl}$ ranging from

A

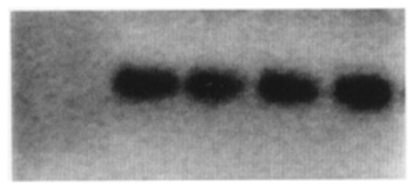

B

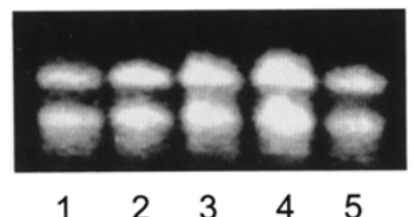

Flig 3. (A)Northern blotting of wild type and some transgenic plants.(B)Total RNA of wild type and some transgenic psants before hybridization. Lane1:Wild type plants Lanes 2-5:different transgenic plants(H9905;H9914; h9928;H9929)

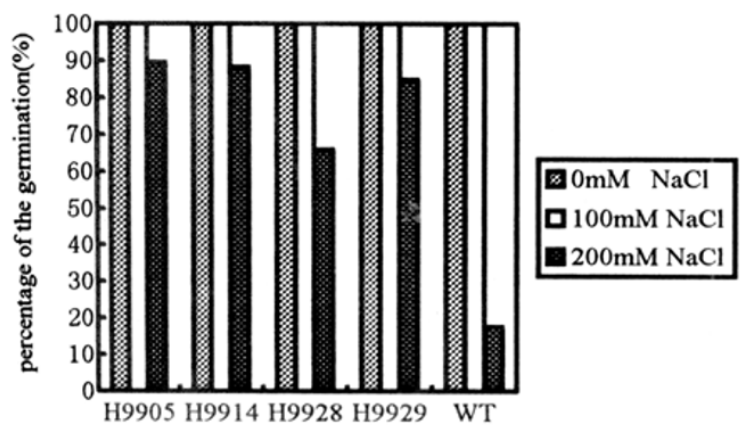

Fig 4. Germination of wild type and some transgenic plants after $7 \mathrm{~d}$ sown on MSmedium with different concentration of $\mathrm{NaC} 1(0,100$, and $200 \mathrm{mM})$
0,100 , and $200 \mathrm{mM} \mathrm{NaCl}$. On the medium with $200 \mathrm{mM}$ $\mathrm{NaCl}$, germination of wild type is $17.7 \%$, whereas the germination of T3 transgenic plants' seeds of line $\mathrm{H} 9905, \mathrm{H} 9914, \mathrm{H} 9928, \mathrm{H} 9929$ is $89.5 \%, 88.4 \%, 65.9 \%$ and $84.9 \%$ respectively (Fig 4 ). The germination of wild type seeds generally decreases greatly at levels higher than $100 \mathrm{mM} \mathrm{NaCl}$, similar to that of other report for wildtype Arabidopsis (Saleki et al 1993[16]). However, the germination of wild type and transgenic plant seeds has no significant difference on MSS $+100 \mathrm{mM} \mathrm{NaCl}$ medium (Fig 4), but after 20 d cultivation on MSS+100 $\mathrm{mM} \mathrm{NaCl}$ medium, leaves of wild type became yellow and ceased to grow, while those of transgenic plant could continue their growth (Fig 5).

T3 kanamycin tolerant plants' progeny (T4 generation) of line H9929 and wild type plant were cultivated under salt or none-salt conditions. Wild-type plants displayed progressive chlorosis, reduced leaf size, and a general growth inhibition when watered with a NaCl-containing solution. These inhibitory effects increased progressively with the increasing $\mathrm{NaCl}$ concentration in the watering solution (Fig6). The transgenic

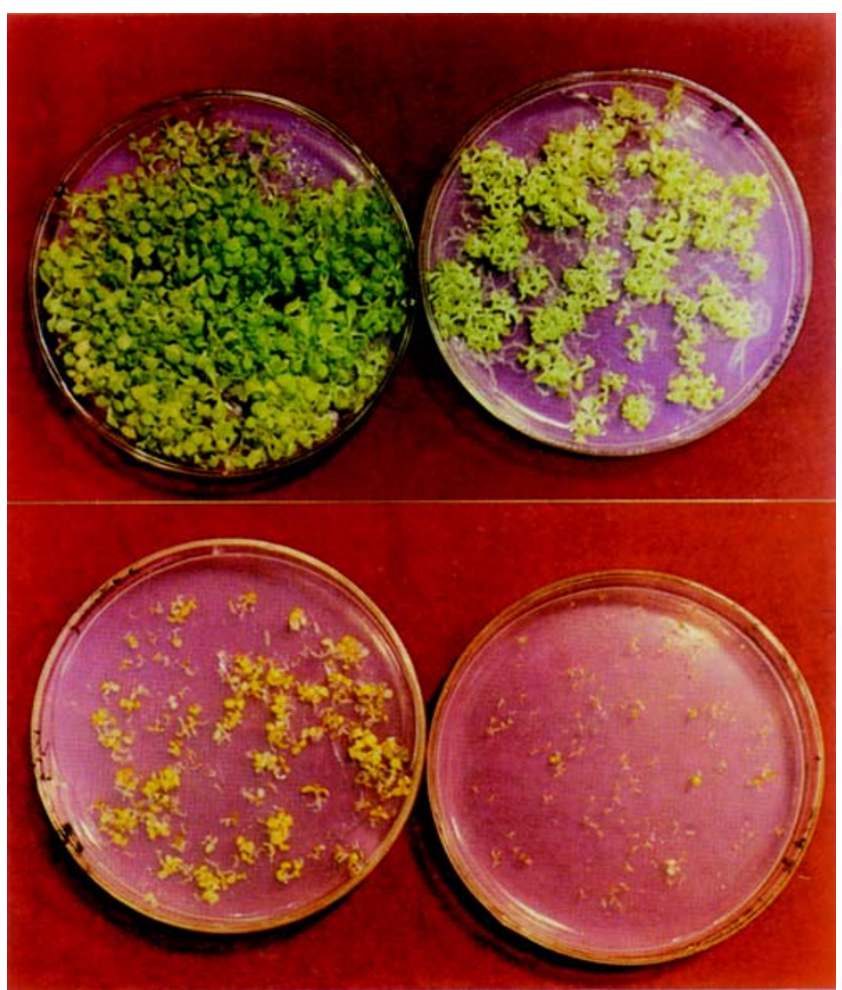

Fig 5. Photograph for T3 transgenic plants of line H9929 (lift Petri dishes)and wild type (right Petri dishes)after 20d cultivation on MSS+100mMNac1 medium(top row)and on MSS+200mMNaC1 medium(bottom row) 
plants of line $\mathrm{H} 9929$ were affected slightly by up to 200 $\mathrm{mMNaCl}$ and plant development was not compromised in all salt treatments (Fig 6). The similar phenomena were also observed in the progeny of line H9905, H9914, and H9928 (data not shown). The above plants were collected for measuring the $\mathrm{K}^{+}$and $\mathrm{Na}^{+}$contents of different parts of plant. In non-stressed conditions, $\mathrm{Na}^{+}$and $\mathrm{K}^{+}$concentrations were very similar in all parts of plant between wild type and T4 generation of line $\mathrm{H} 9929$. The $\mathrm{Na}^{+}$content in all parts of plant increased when exposure to high concentration of $\mathrm{NaCl}$ (Fig 7). The $\mathrm{Na}^{+}$concentrations of transgenic progeny of line H9929 are lower than wild type plant in all various tissues, while $\mathrm{K}^{+}$concentrations have no notable difference between wild type and the progeny of transgenic plants line H9929 (Fig 8).

The ratio of $\left[\mathrm{K}^{+}\right]$to $\left[\mathrm{Na}^{+}\right]$was decreased accompanying the increasing concentration of $\mathrm{NaCl}$, but it was higher in the transformed lines than in wild type plant under both salt-stressed and non-stressed conditions in all types of tissues except roots (Tab 2). It has also been shown that the ratio of $\left[\mathrm{K}^{+}\right]$to $\left[\mathrm{Na}^{+}\right]$in the top tissue is higher than the other tissue in all condition for wild type and H9929. Similar results were also confirmed in T4 generation of line H9905, H9914, and H9928 (data not shown).

Tab 2. The changes of $[\mathrm{K}+] /[\mathrm{Na}+]$ in different tissues in the T4 generation of line H9929 and wild type when exposed to $\mathrm{NaCl}$ stress

\begin{tabular}{lcccccc}
\hline Tissue & \multicolumn{2}{c}{$0 \mathrm{mM}$} & \multicolumn{2}{c}{$50 \mathrm{mM}$} & \multicolumn{2}{c}{$200 \mathrm{mM}$} \\
\cline { 2 - 7 } & $\mathrm{H} 9929$ & WT & H9929 & WT & H9929 & WT \\
\hline Top tissue & 6.13 & 4.43 & 0.96 & 0.21 & 0.32 & 0.17 \\
Middle tissue & 4.38 & 3.76 & 0.56 & 0.16 & 0.31 & 0.11 \\
Lower tissue & 1.42 & 0.83 & 0.16 & 0.08 & 0.13 & 0.09 \\
Root & 0.95 & 1.00 & 0.20 & 0.09 & 0.08 & 0.09 \\
\hline
\end{tabular}

A

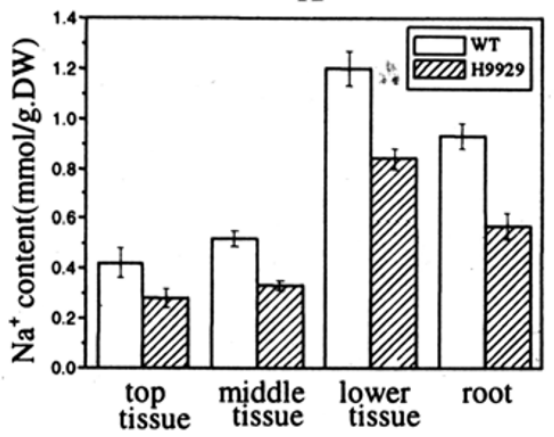

\section{DISCUSSION}

Over-expression of HAL1 gene in yeast confers a high salt tolerance level by reducing $\mathrm{K}^{+}$loss and de-

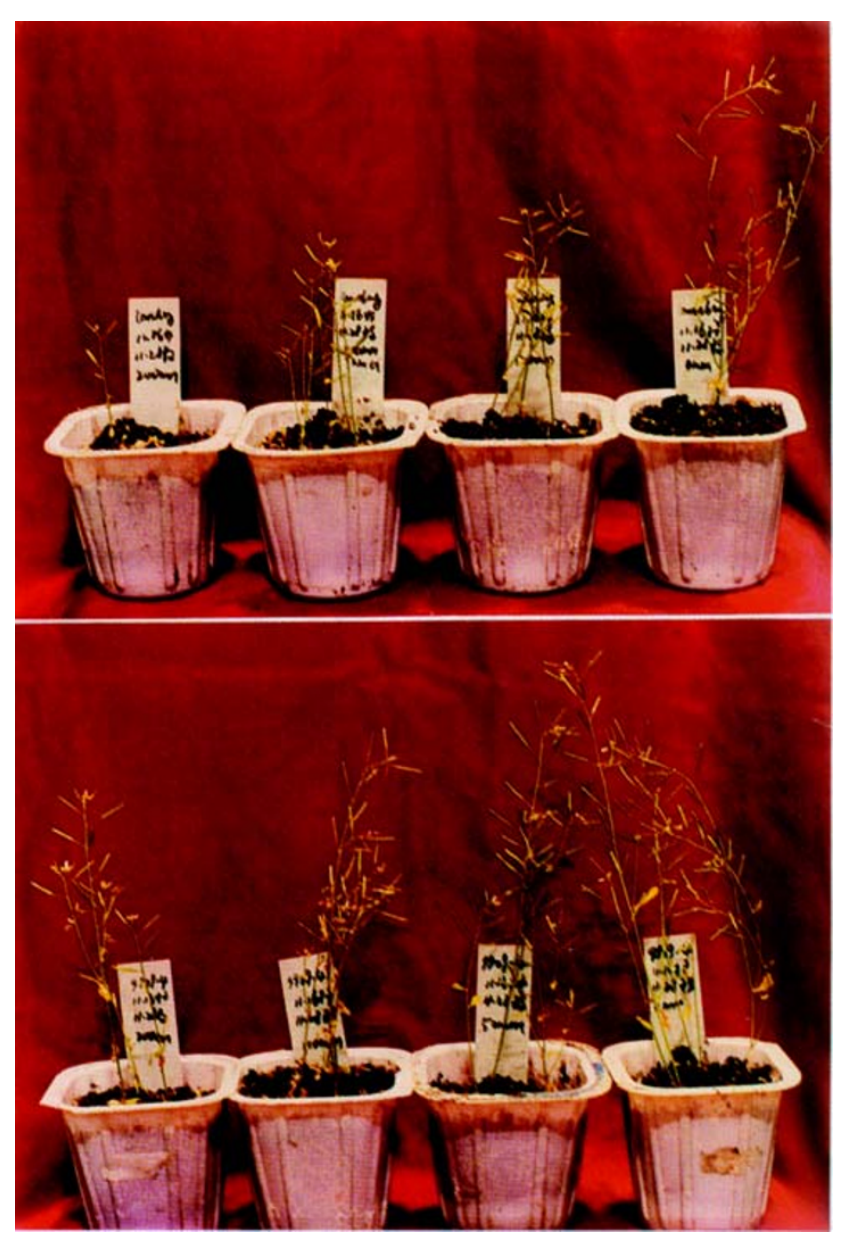

Fig 6. Phenotypes of wild type (top row)and T4 transgenic plants of line H9929(bottom row)under different livels salt stress. (From left to right the concentrations of $\mathrm{NaCl}$ were $200 \mathrm{mM} 100 \mathrm{mM}, 50 \mathrm{mM}$, and $0 \mathrm{mMrespectively.)}$

Fig 7. The $\mathrm{Na}^{+}$content in the tissues of wild type and the T4 transgenic plants of line $\mathrm{H} 9929$ under different concentration of NaCLtreatments. A. $0 \mathrm{mMNaCl} ; \mathbf{B} .50 \mathrm{mMNaCl} ; \mathrm{C} .200 \mathrm{mM} \mathrm{NaCl}$. 
A

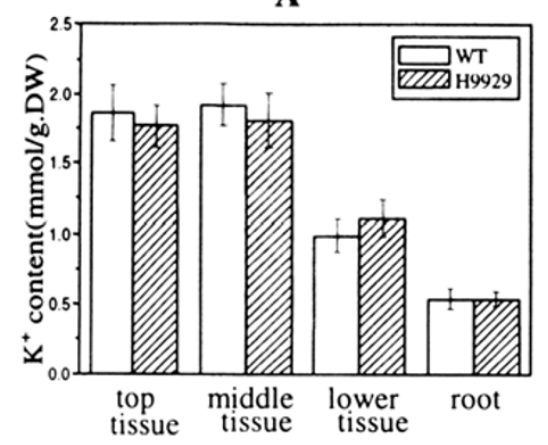

B

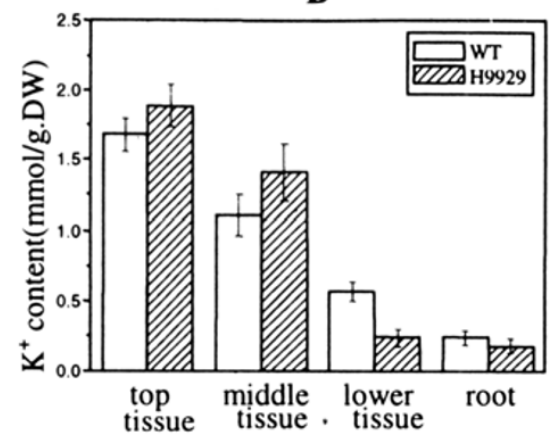

C Yang SX et al

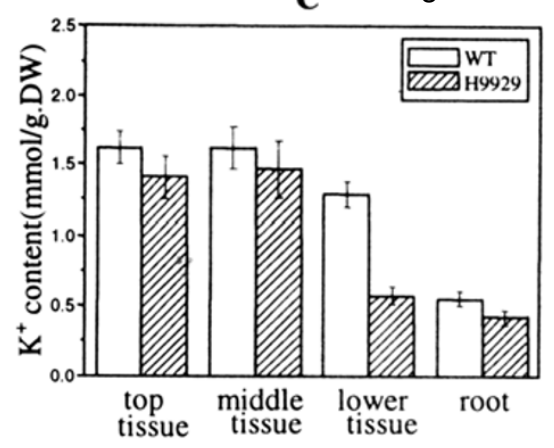

Fig $8 \mathrm{TheK}^{+}$content in the tissues of wild type and the T4 transgenic plants of line $\mathrm{H} 9929$ under different concentration of $\mathrm{NaCl}$ treatment. A. $0 \mathrm{mMNaCl} ; \mathrm{B} .50 \mathrm{mM} \mathrm{NaCl} ; \mathrm{C}$. $200 \mathrm{mMNaCl}$.

creasing intracellular $\mathrm{Na}^{+}$from the cells upon salt stress. The PMR2/ENA1 gene, corresponding to a major $\mathrm{Na}^{+}$efflux system, mediated the effect of HAL1 on intracellular $\mathrm{Na}^{+}$. The effect on intracellular $\mathrm{K}^{+}$was mediated by an unidentified $\mathrm{K}^{+}$efflux system[8]. In this work, the concentrations of $\mathrm{Na}^{+}$in the transgenic Arabidopsis plants showed a tendency to accumulate less $\mathrm{Na}^{+}$under saline conditions than wild type plants, which is in accordance with the result of over-expressing the HAL 1 in yeast and that in a recent publication in tomato[4]. It suggests that the activity of $\mathrm{Na}^{+}$efflux may be up regulated by HAL1 in the transgenic Arabidopsis plants.

According to the two-phase salt response hypothesis, plant growth is first inhibited by cellular response to the osmotic effects and latter by the toxic effects due to excessive salt accumulation in plant cell[17]. These responses were also observed at different levels of salt tolerance in wild type (Arabidopsis thaliana) and transgenic plants in this work. The germination and growth of transgenic plants and wild type plants on MSS $+100 \mathrm{mM}$ $\mathrm{NaCl}$ medium indicated that salt tolerance conferred by HAL 1 mainly through mitigation of toxic effects of salt stress in transgenic plants. It is identical to the over-expression of HAL1 gene in yeast under salt stress[8]. Though both $\left[\mathrm{K}^{+}\right] /\left[\mathrm{Na}^{+}\right]$of transgenic Arabidopsis and tomato increases, but transgenic tomato managed it through retaining more $\mathrm{K}^{+}$and accumulating less $\mathrm{Na}^{+}$, while transgenic Arabidopsis largely by accumulating less $\mathrm{Na}^{+}$. It should be noted that by now only two transgenic studies of HAL1 in plants were studied in vitro and in the initial generations of transgenic plants $[4,10]$. In melon, only T1 transgenic plants were evaluated for salt tolerance using a shoot-apex test in vitro[10]. In tomato, most of salt tolerance evidence was obtained from T2 transgenic plants (F2 generation in the classical genetic analysis, including heterozygous and homozygous plants) in vitro, although in vivo physiological response were also tested in T3 or T2 transgenic plants, the stress concentration of $\mathrm{Na}^{+}$used is only at moderate level $(75 \mathrm{mM})[4]$.

It also should be pointed out that salt tolerance levels of several populations of transgenic Arabidopsis plants in this work were higher than previously studied in tomato and melon. This could be explained by the effect of the genetic background of the species, but the facility for genetic manipulation in Arabidopsis should also be considered. As a model plant for molecular biology studies, adequate transgenic Arabidopsis plants and their progeny could be obtained easily. Its small size allows us to conduct a lot of salt tolerance tests for all kanamycin tolerant lines before further physiological experiment. Their short life cycle is more favorable to get the homozygous progeny during a limited time. This may help us to eliminate the variation from either genetic or epigenetic elements. Although more studies are necessary to carry out before being able to conclude whether the HAL1 gene could be proved useful in generating a cultivars with agronomic interest. The results obtained in this study, however, indicate that over expression of HAL1 gene can promote a high level of salt tolerance in transgenic Arabidopsis plants.

\section{ACKNOWLEDGMENTS}

The project was founded by a grant from State 863 National High Technology Research Development Project of China, No. 819-0803.

\section{REFERENCES}


[1] Tarczynski M, and Bohnert H. Stress protection of transgenic tobacco by production of the osmolytemannitol. Science 1993; 259:508-10.

[2] Kavi Kishor PB, Hong zonglie, Miao Guo-Gua, Hu CheinAn A, Verma Desh Pal S. Over-expression of Ibigtriangleup1-Pyrroline-5-Carboxylate synthetase increase proline production and confers osmotolerance in transgenic plants. Plant physiology 1995; 108:138794.

[3] Lilius G, Holmberg N, Búlow L. Enhanced $\mathrm{NaCl}$ stress tolerances in transgenic tobacco expressing bacterial choline dehydrogenase. Biotechnology 1996; 14:17780.

[4] Carmina Gisbert, Ana M Rus, M Carmen Bolar in, J Miguel $L_{o}$ pez-coronado, isabel Arrillaga, consuelo Montesinos, Manuel Caro, Ramon Serrano, Vicente Moreno. The yeast HAL1 gene improves salt tolerance of transgenic tomato. Plant Physiology 2000; 123:393402.

[5] Apse Maris P, Aharon Gilad S, Snedden Wayne A, Blumwald Eduardo. Salt tolerance conferred by over-expression of a vacuolar $\mathrm{Na} / \mathrm{H}$ anti-port in Arabidopsis. Science 1999; 285:1256-8.

[6] Pardo JM, Reddy MP, Yang SL, Maggio A, Huh GH, Matsumoto T, Coca MA, Painodurzo M, Koiwa $H$, Yun DJ, Watad AA, Bressan RA, Hasegawa PM. Stress signaling through $\mathrm{Ca}^{2+} /$ calmodulin-dependent protein phosphatase calcineurin mediates salt adaptation in plants. Proc Natl Acad SciUSA 1998; 95:9681-6.

[7] Serrano R. Salt tolerance in plants microorganismstoxicity targets and defense responses. Int Rev Cytol 1996; 4:281-287

[8] Gaxiola Roberto, Larrinoa Inigo F de, Villalba Jose M,
SerranoRamon. Anoveland conserved salt-induced protein is an important determinant of salt tolerance in yeast. TheEMBO Journal 1992; 11:3157-3164.

[9] Rios Gabino, Ferrando Alejandro, Serrano Ramon. Mechanisms of salt tolerance conferred by over-expression of the HAL1 gene in Saccharomyces cerevisiae. Yeast 1997; 13: 515-528.

[10] Bordá s M, Montesinos C, Dabauza M, Salvador A, Roig LA, SerranoR, MorenoV. Transfer of theyeastsalt tolerance gene HAL1 to CucumismeloL. Cultivarsand invitroevaluation of salt tolerance. Transgenic Research 1997; 5:1-10.

[11] Murashige T, Skoog F. A revised medium for rapid growth and bioassay with tobaccotissue cultures. Physiology Plant 1962; 15:473-97.

[12] Hoekema A, Hirsch PR, Hooyakass PJ, Schilperoort RA. $A$ binary plant vector strategy based on separation of vir-and T-region of the Agrobacterium tumefaciens $\mathrm{Ti}$ plasmid. Nature 1983; 303:179-80.

[13] Bevan MW. Binary Agrobacterium vector for plant transformation. Nucleic Acid Research 1984; 12:87118723. Bechtold N, Ellis J, Pelletier G. In planta Agribacterium mediated gene transfers by infiltration of Adult Arabidopsis thaliana plants. C R Acad Sci 1993; 316:1194-9.

[14] Maniatis T, Fritsch EF, Sambrook J. Molecular cloning: A Laboratory Manual. Cold Spring Harbor Laboratory Press 1982:498-501.

[15] Saleki R, Young PG, Lefebvre DD. Mutants of Arabidopsis thaliana capable of germination under saline conditions. Plant Physiology 1993; 101:839-45.

[16] Munns R. Physiological process limiting plant growth in saline soils: some dogmas and hypotheses. Plant Cell Environ 1993; 16:15-24

[17] Munns R. Physiological process limiting plant growth in saline soils: some dogmas and hypotheses. Plant Cell Environ 1993; 16: 15-24. 